\title{
THE FAILURE OF THE SHERMAN ANTI-TRUST LAW
}

The Supreme Court of the United States has spoken once more on the Sherman Anti-Trust Law and the community is again ordered to revise its opinion on that subject. Recently, that court rendered two decisions in which it was decided that the plan or scheme adopted by the Cement ${ }^{1}$ and Maple Flooring Associations " was intended merely as a means of disseminating information and knowledge to those engaged in those two industries, and not as a means of evading the Sherman Law. On October 12, 1925, the Supreme Court denied the Government's application for a rehearing of these cases.

The casual student of the Anti-Trust Law may regard the decisions as harmless for the Supreme Court declared in its opinion that the decision for the defense was based solely on the Government's failure to state and prove a case. But those who have been charged with the administration of the Sherman Law and who are acquainted with the practices of trade associations feel confident that these two decisions of the Supreme Court will result in a revival of the illegal practices with which the community had been afflicted.

The facts in the Maple Flooring case and in the Cement case are more or less identical. They represent a new species of pricefixing agreement: a hybrid of the price-fixing agreement and of the Eddy Open Price Plan.

The History and Development of Price Regulation by Combination Agreements

"Price fixing," when used in connection with combination agreements, denotes the control of a substantial part of an industry by a combination which has destroyed the normal functioning of the law of supply and demand. It does not necessarily mean the fixation of uniform sale prices by the members of the com-

\footnotetext{
${ }^{2}$ Cement Manufacturers' Protective Assn., et al., v. U. S., 268 U. S. $\$ \& 3$ (1924).

'Maple Flooring Manufacturers Assn., et al., v. U. S., 268 U. S. 563 (1924).
} 
bination; on the contrary, such an agreement in recent years is rare.

Price regulation in industry has undergone various changes during the last thirty-five years. The first task of such combinations was to circumvent the Sherman Law; the second task, to counteract the effect of a depression in the market resulting in reduced prices.

\section{(A) An Early Form of Price-Fixing Arrangement}

In its elementary stage, and in its crudest form, price-fixing was an operation engaged in by the leaders of an industry who controlled from about thirty to sixty per cent. of a commodity. Since production was not limited to the probable demand for the commodity at the fixed price, the law of supply and demand worked havoc with those price-fixing agreements. Therefore, in the early nineties experience gave to these combinations their first lesson in economics. They learned that a manufacturer cannot keep hoarding his wares forever; that there is a limit to his endurance. They found that when production leaps far beyond demand, economic law establishes the sale prices of the commodity in the market, combination agreements to the contrary notwithstanding.

This type of agreement had another inherent weakness. The combinations were comprised of the leaders in the industry. The small manufacturer was completely disregarded. The combinations found as time went on that these small manufacturers gave severe combat; they unconsciously hindered the proper execution of the combinations' agreement. Interest on the capital investment and the cost of overhead in a small business constitute an almost negligible item in figuring the cost of production. By underselling their leading competitors, the small manufacturers kept increasing the size of their business.

The great combinations, thereupon, were compelled to devise a scheme to entice the small manufacturers. They recognized that it would be idle to ask a small manufacturer to join the combination and to charge the fixed price, for with equality of price, the retailer would rather deal with the established house. The idea was conceived of giving these small manufacturers an advantage. 
The members were divided into various classes, the leaders agreeing to charge the fixed price, and those in the remaining classes being permitted to charge two, five and in some instances fifteen per cent. less than fixed price.

The combination is a very powerful institution in an industry. Yet it by no means wields the power with which it is invested in the mind of the small American business man. If it is pointed out to him by the leaders of an industry that by joining the assuciation his net profits may be enhanced though the size of his business will remain stationary, it is seldom that he declines the invitation to join the combination. The man with a small but profitable business would generally prefer to develop it in his own way, hopeful that in years to come he will be the leading figure in the. industry. He recognizes that to join the combination means def-erence to the leaders. It is difficult for him to agree to place himself in a position where his own business policy ceases to be a factor, and his business judgment divorced from the movements in the industry. Fear that failure to join the combination woul ${ }^{2}$ mean destruction, coupled with the knowledge that association with it would mean even a much greater security than he enjoyed theretofore, impel him to become a member of the combination.

An arrangement whereby production was limited, prices fixed and in some instances particular territory allocated to the various members was the customary combination agreement in $n^{2} i 1$ about 1919. Since then this type of agreement has also fallen into discard and an improved arrangement has taken its place.

It is the purpose of all illegal trade combinations to charge the highest possible price without unprofitably diminishing demand. Combinations found during the war period that their agreements were not sufficiently elastic to provide for the 2 vantages in sales prices to be derived from an excellent sellers' market.

\section{(B) The Latest Form of Price-Fixing Agreemeni}

The price-fixing agreement in its perfect form limits the amount of production and fixes a minimum sale price. The smail manufacturer generally charges the fixed minimum sale price. 
The others charge higher amounts, dependent upon the reputation of their firm names. Again, in some industries, the firm name is of more importance than in others. Of course, all members of the combination try to get varying amounts in excess of the minimum price.

It is obvious that for a space of time immediately after the making of the agreement, there is an adjustment of prices by the members of the combination. Some begin by asking prices lower than those they could obtain in the market; others begin by asking prices that are so excessive that, before long, lack of orders compels them to reduce their prices. It should be recognized that in the absence of this minimum price fixation, the probability is that these minimum prices would be the prevailing market prices.

Most business men are not so adventurous that they will agree on a minimum price; it is probable that such an agreement would be held to be illegal. Therefore, the approach is entirely different; they agree to have a. joint cost accounting system. Each member under the supervision of the association, determines the cost of the raw material that enters into each piece of the commodity, the cost of production, the cost of overhead, depreciation, interest on investment, et cetera. In many corporations, excluding the gigantic corporate entities, the officers are the sole stockholders or the majority stockholders of the corporation. Their salaries, which are usually set at an amount extremely in excess of the actual value of their services, are included either in the cost of overhead or in the cost of production.

It is needless to say that the members fix their respective costs of production at the highest possible amount; the general public, which in a sense constitutes the adversary, is not represented and does not partake in the determination. The average cost of production to the members is taken by the association as the actual cost of production. Thereafter, at association meetings or at other conferences of the members of the combination, "the cost of production" will be referred to as though the amounts had been determined by scientific methods, and as though it were the same for all the members. Before long, the members attain 
the state of mind that this "cost of production" actually represents cost on which prices must be based.

To assist each other in determining the prices that can be charged, the members circulate weekly, either personally or through the association, the prices at which they made their sales. These reports may inform one member that his prices are lower than the others in his class and he naturally increases them; it may tell another member that his prices are higher than the others in is class and he will decrease his prices.

In order to keep production to the point where these prices can be obtained, the members report weekly to the association the amount of production on hand, and the extent of the orders received. The secretary of the association collates this information and immediately distributes it to the members. In that way production is limited to the probable demand for the commodity at the prices determined by the members of the combination.

There is one other aspect to the situation. Certain members in almost all trade combinations are advantageously situated geographically. ${ }^{3}$ To destroy this advantage and to put all members on the same basis, freight rates are almost invariably equalized. Sometimes, the combination agrees on one arbitrary point and to the sale price is added the amount that the purchaser would have paid for freight if he had bought the merchandise from a seller at that arbitrary geographical point. Even if the purchaser buys his merchandise from a member of the combination having a mill adjacent to the purchaser's place of business, the purchaser, nevertheless, must pay this fictitious freight charge.

Within the writer's experience, he has never found a trade combination that equalized freight rates that did not operate under some form of price-fixing agreement. It may take the form wherein the leader of the industry issues a price bulletin to his customers and the other members of the combination follow those prices in making sales to their customers, or price-fixing may be operative as a result of an arrangement fixing base list prices with

s "It is obvious that no more powerful instrument of monopoly could he used than an advantage in the cost of transportation." Swift v. U. S., rg6 U. S. 401, 402 (1905). 
certain discounts to be invoked. Or price-fixing may exist as in the perfect scheme by using a fictitious uniform cost accounting system which in effect fixes minimum sales prices.

A few years ago the Department of Justice investigated a combination which it had reason to believe violated the Sherman Law. The most careful examination of the minutes of its meetings, the correspondence between the association and its members and the correspondence of the members failed to disclose evidence of price-fixing. The fact remained, however, that the combination equalized freight rates: a circumstance usually indicative of a price-fixing agreement.

Careful scrutiny disclosed the fact that there was a trade journal in the industry. This publication issued by members of the association contained surveys with regard to the future of the industry and prices predicted by the editor for the ensuing months. The predicted prices were the prices actually fixed by the combination.

No valid reason can be asserted for the equalization of freight rates except as a means of supporting and sustaining arbitrary sale prices in the market. Scepticism of dogmatic declarations may cause one to pause at the statement; experience, however, with combinations compels that conclusion.

II

\section{The Decision in the Maple Flooring Case Contrasted With Prior Decistons}

It has already been indicated that the facts in the Cement and Maple Flooring cases are practically alike. For purpose of brevity, the discussion will be limited to the Maple Flooring combination.

In that case, the Government showed that the present scheme was an outgrowth of a price arrangement which existed among the defendants in which the defendants not only fixed the prices of this commodity but in addition allotted a percentage of the aggregate shipments to the various members of the Association. The Government also showed that a booklet had been issued by the Secretary of this Association, wherein appeared the sale price 
of the commodity and the amount that would be added for freight. In other words, under the old plan the defendants went so far as to print the fixed net sale price to be charged by each member of the Association.

In 192 I the Association received a letter from the Assistant to the Attorney-General stating that the agreement constituted a flagrant violation of the Sherman Law. ${ }^{4}$ In addition to this reproval came active prosecution of the Sherman Law violations during the years $1921-1923$.

The defendants, thereupon abandoning their old plan, entered into a so-called gentlemen's agreement, providing for the distribution and dissemination of reports with reference to the business of each and every member of this Association. ${ }^{5}$

The bill in equity filed by the Government ${ }^{6}$ alleged in substance that the defendants by agreement fixed minimum prices upon the commodity, and controlled its production and prices in the market by the observance of provisions contained in the plan of the Association, which provided for the computation and distribution among the membership of alleged average costs, being in fact agreed minimum prices, for the adoption and distribution of freight rate books, for an open price reporting plan, and for meetings of the members of the Association.

The Government also charged that the plan or scheme adopted by these defendants had a direct and necessary tendency to destroy competition, that the methods employed by them tended at all times to impede the operation of the laws of supply and demand, and that the effect was to stifle competition contrary to the intendment of the Sherman Law.

The Government proved that pursuant to this "gentlemen's agreement," the members of this Association reported weekly to the Secretary of the Association on printed forms, giving complete data as to sales made by the reporting members; quantity, thickness, face, grade and kind of wood; delivery, sales prices, average freight rate to destination, and rate of commission paidz.

'Trial Record, Vol. IV, p. 802.

'Trial Record, Vol. III, p. 70.

- Trial Record, Vol. I, pp. I-12. 
The members also reported the amount of flooring on hand of each dimension and grade, and the amount of unfilled orders. Monthly reports were also required showing the amount of production for each period and the new orders booked for each variety of flooring. The Association promptly reported back to the members statistics compiled from these reports and information as to quantities, grades, prices and freight rates, with respect to each sale. ${ }^{7}$

To realize the complete benefit of the old plan, the combination continued to equalize freight rates. Since the plants of the members of this Association were located in five states: Michigan, Minnesota, Wisconsin, with one plant in Illinois and another as far east as New York, the charge for freight would be a vital factor to the prospective purchaser in determining where to make his purchase. To make the scheme complete, the defendants agreed that the freight to be charged to the purchaser should be based arbitrarily on the freight charge from Cadillac, Michigan. ${ }^{8}$

At the trial one of the defendants, a member of the Market Conditions Committee of the Association, testified as follows: ${ }^{9}$

"A. The general market conditions were always discussed; yes.

Q. And the range of prices?

A. Sometimes."

"A. There is no question at all if I went to one of those meetings, I went there to get information if $I$ could as to market conditions, and the reason I wanted that information was to know what I would do with my prices; yes. the time?

Q. That was the ultimate object you had in mind all

A. Absolutely. for?

Q. That is what you wanted all of this information

A. Why, it would be useless to us for any other purpose.

Trial Record, Vol. III, p. 70.

"Trial Record, Vol. I, p. II2; Vol. IV, p. 433.

- Testimony of Witness Ralston, Trial Record, Vol. I, pp. 330-33I. 
$Q$. And that is the reason all of you exchanged all this information about yourselves, was it?

A. Yes, it was spoken of that way."

In the course of its argument before the Supreme Court, the defense admitted that dissemination of this information as to the cost of the product, and as to production and prices, would tend to bring about a uniformity in prices.

Since the Supreme Court in these two decisions reaffirms the doctrine that an agreement to fix prices is in contravention of the Sherman Act, is it too much to have expected that it would brand this agreement as one within the prohibitions of that law? Do business men combine to install a joint cost accounting system, pay the expense involved to carry on this scheme, and retain a secretary and other experts for the correlation of this information, if they do not intend to be guided by the information in fixing their prices?

We would expect that the defendants' admission would have been sufficient in and of itself to convince the Court that the inherent characteristics of this agreement placed it completely within the category of a price-fixing arrangement.

It is inconceivable that the Highest Court of the Land would seriously entertain the argument of the defense that a member of this Association having his plant in New York and making a sale in Colorado would be willing to pay the freight rates of a. heavy shipment from New York to Cadillac, Michigan, to save a purchaser the trouble of ascertaining the freight rate from the seller's place of business to the purchaser's place of business.

If the Supreme Court's decision is based on the insufficiency of the Government's allegations, then the proper course for that Court to have pursued was to deny the application on that ground. While statements to that effect are set forth in the opinion of $\mathrm{Mr}$. Justice Stone who wrote for the majority, the fact remains that the Supreme Court decided the case on its merits, and held the plan to be completely innocuous.

It seems obvious when we comb the facts that this represented the modern type of price-fixing agreement. Sale price vis not to be based in a competitive market on cost plus profit i. 
- instead, on a fictitious average cost to the members of the combination and a profit that could be exacted after production had been manipulated and limited. Assuming, however, that it was not an agreement whereby prices were actually fixed, the fact does remain that the defendants entered into an agreement to give to each other all the information with regard to their own business so that they would all be enabled to have a basis for fixing their individual prices. As the Government argued in its brief ${ }^{10}$ submitted to the Supreme Court, the very foundation of competition consists of the difference in the cost of production and of distribution. It is that difference which enables one competitor to undersell another, and with its elimination competition practically disappears.

It was the aim and purpose of the Sherman Law to protect the public against any artificial means adopted either by combinations of capital or of labor to thwart the functioning of the ordinary economic laws. ${ }^{11}$ The creation of an artificial force which places the power to control production and prices in the hands of a combination cannot be said to foster competition.

It should not be overlooked that the mere agreement to impede or stifle competition is a violation of the Sherman Law. ${ }^{12}$ It was the opinion of the legislative authority that the public is assured the greatest benefit by competitive enterprise. ${ }^{13}$ Experi-

${ }^{10}$ Pages 6r-62.

${ }^{11}$ Gompers v. Buck Stove \& Range Co., 22I U. S. 4I8, 438 (I9ro) ; Eastern States Lumber Asso. v. U. S., 234 U. S. 600, 608, 618 (I9I4); Thomsen v. Cayser, 243 U. S. 66, 84, 85, 86 (I9I6) ; U. S. v. American Linseed Oil Co., et al., 262 U. S. 371 (1922).

${ }^{12}$ U. S. v. Trans-Missouri Freight Asso., I66 U. S. 290, 323 (1896) ; Addyston Pipe \& Steel Co. v. U. S., 85 Fed. 271, 291 (I898); Affd. 175 U. S. 211 (1899); Dr. Miles Med. Co. v. Parks \& Sons Co., 220 U. S. 373, 407 (1910); U. S. v. A. Schrader's Sons, 252 U. S. 85, roo (r9r9) ; Standard Sanitary Mfg. Co. v. U. S., 226 U. S. 20 (IgII) ; Swift \& Co. v. U. S., stpra, note 3.

${ }^{23}$ The great purpose of both (referring to Sherman and Clayton Acts) was to advance the public interest by securing fair opportunity for the play of the contending forces, ordinarily engendered by an honest desire for gain." Federal Trade Commission v. Sinclair Refining Co., 261 U. S. 463,476 (1922).

"It has been suggèsted that we should have regard to new commercial conditions and a tendency toward a relaxation of old common-law principles which tend to prevent development on modern lines. This is an argument better addressed to legislative bodies than to the courts. Neither is it wise for the courts to countenance the introduction of artificial distinctions de- 
ence may have convinced that authority that Philip Spencers are rarely found in trust combinations. Whereas, that body might also have found that to create monopoly prices is the usual practice of such combinations.

The Court's findings of fact in the Maple Flooring case that the sale prices of the defendants varied should not have affected its decision. The prior decisions of that Court did not condemn price-fixing merely because of symmetry of prices. It is immaterial whether curtailment of production and the fixation of prices constituted the agreement or whether the agreement was to bring a foreign force into play so that supply and demand no longer determined the sale price of the commodity. Any device or simulation which is substituted for competitive enterprise equally denies to the public the benefits to be derived from the free movement of trade and commerce.

The situation is not altered by the Court's finding that prices in this industry have receded to the same extent that they have in other industries. There is no means of determining the sale prices that would have obtained in this particular industry in the absence of this artifical barrier. Furthermore, the Supreme Court was without knowledge as to whether combination agreements were not responsible for the sales prices that existed in those other industries which it studied and examined.

pendent upon the variant economic views of individual judges. Distinctions which are specious or analogies which are but apparent will but afford opportunities to whittle away broad economic principles lying at the bottom of our public policy, principles which have long received the sanction of statesmen and the approving recognition of a long line of jurists. A like argument is expected whenever some new method of circumventing freedom of commerce comes under the tests of the law. It was made and answered by Judge Taft in the Addyston Pipe Case with a strength to which we can add nothing."

The closing remarks of Circuit Judge (subsequently Mr. Justice) Lurton in John D. Park \& Sons Co. v. Hartman, 153 Fed. 24, 46 (I907):

". . in view of the general language of the Statute and the public policy which it manifested, there was no possibility of frustrating that policy by resorting to any disguise or subterfuge of form, since resort to reason rendered it impossible to escape by any indirection the prohibitions of the statute." U. S. v. Amer. Tobacco Co., 221 U. S. 106, I8I (1910).

See also: Swift \& Co. v. U. S., supra, notes 3, 12; U. S. v. Reading Co., 226 U. S. 324, 358 (IgI2); Standard Sanitary Mfg. Co. v. U. S., supra, note 12; International Harvester Co. v. Missouri, 234 U. S. I99 (I9I4); Thomsen v. Cayser, supra, note II. 
For the Supreme Court to declare, that this agreement is legal because the power has not been exercised to the injury of the public, repudiates all prior decisions of that Court. Theretofore, that Court had declared in the boldest language that the law is exerted against the sinister potential power that follows the execution of such an agreement. ${ }^{14}$

Mr. Justice McReynolds' dissent in the Maple Flooring case is entitled to very careful examination. ${ }^{15}$

"These causes disclose carefully developed plans to cut down normal competition in interstate trade and commerce. Long impelled by this purpose, appellants have adopted various expedients through which they evidently hoped to defeat the policy of the law without subjecting themselves to punishment.

"They are parties to definite and unusual combinations and agreements, whereby each is obligated to reveal to confederates the intimate details of his business and is restricted in his freedom of action. It seems to me that ordinary knowledge of human nature and of the impelling force of greed ought to permit no serious doubt concerning the ultimate outcome of the arrangements. We may confidently expect that destruction of that kind of competition long relied upon by the public for establishment of fair prices, and to preserve which the Anti-Trust Act was passed. . . ."

\section{III}

\section{A Paradox: The Decisions Regarding the Perfect Price-Fixing Arrangement}

In I919, the Department of Justice had a number of cases under consideration in which combinations were operating under the newly conceived price-fixing plan previously discussed. There were at that time no Supreme Court decisions determining or discussing its legality.

In building up a record in a case before a court of first instance, a government prosecutor may at times overlook an im-

14 Trans-Missouri Freight Asso. v. U. S., Mtpra, note 12; U. S. v. Addyston Pipe \& Steel Co., supra, note 12; Thomsen v. Cayser, supra, note II; Swift v. U. S., supra, notes 3, 12, 13; American Column \& Lumber Co., v. U. S., 257 U. S. 377 (Ig2I), and U. S. v. American Linseed Oil Co., supra, note II.

${ }^{\text {is }} 268$ U. S., at page 587 . 
portant fact. Realizing that, it was the judgment of the Department of Justice to proceed with its weakest case first. The first case of this type presented to the Supreme Court of the United States was the prosecution against the American Column and Lumber combination, commonly referred to as the Hardwood Lumber case. ${ }^{10}$ In that case, the combination through its secretary merely distributed prices charged by the members and quantity of production on hand. There was no agreement to operate under a fictitious cost accounting system. It was believed that if the Supreme Court would decide that case in favor of the Government it would surely decide all the others in the same way.

After hearing argument and reargument in the Hardwood Lumber case, the Supreme Court in I92I rendered its decision. It held that the Hardwood Association was a combination in restraint of trade. Justices Holmes, McKenna and Brandeis dissented; Mr. Justice Clarke, speaking for the majority of the Court, declared : ${ }^{17}$

'The 'Plan' is, essentially, simply an expansion of the gentlemen's agreement of former days, skillfully devised to evade the law. To call it open competition because the meetings were nominally open to the public, or because some voluminous reports were transmitted to the Department of Justice, or because no specific agreement to restrict trade or fix prices is proved, cannot conceal the fact that the fundamental purpose of the 'Plan' was to procure 'harmonious' individual action among a large number of naturally competing dealers with respect to the volume of production and prices, without having any specific agreement with respect to them, and to rely for maintenance of concerted action in both respects, not upon fines and forfeitures as in earlier days, but upon what experience has shown to be the more potent and dependable restraints of business honor and social penalties; cautiously reinforced by many and elaborate reports, which would promptly expose to his associates any disposition in any member to deviate from the tacit understanding that all were to act together under the subtle

13 American Column \& Lumber Co., et al., v. U. S., supra, note I4.

${ }^{27} 257$ U. S. 377, 4I0-4II (I921). 
direction of a single interpreter of their common purposes as evidenced in the minute reports of what they had done and in their expressed purposes as to what they intended to do."

Thereupon followed a number of other prosecutions. The most prominent being that against the Linseed Oil combination. ${ }^{18}$ In every case the Supreme Court condemned the scheme as an artificial means adopted by a combination to circumvent the Sherman Law. The Supreme Court was vehement in its language. Speaking of competition, in the Linseed Oil case, it said: ${ }^{10}$

"The Sherman Act was intended to secure equality of opportunity and to protect the public against the evils commonly incident to monopolies and those abnormal contracts and combinations which tend directly to suppress the confict for advantage called competition,- the play of the contending forces ordinarily engendered by an honest desire for gain."

The decision in the Hardwood Lumber case was rendered by the Supreme Court in I921. Since then there have been a number of changes on the Supreme Court, and Mr. Justice McReynolds and Chief Justice Taft, who at that time voted with the majority, have now become the minority, and Mr. Justice Holmes and Mr. Justice Brandeis, who in the Hardwood Lumber case were in the minority, have now become members of the majority.

Mr. Justice Brandeis in his dissenting opinion in the Hardwood Lumber case, asserted that the agreement merely regulated business, the very same idea that we now find in the majority opinion of Mr. Justice Stone. Mr. Justice Brandeis has not a tremendous amount of faith in a competitive system, nor does he lend himself kindly to any legislation designed to keep a competitive system alive, feeling that good judgment should lead a community to regulate business, especially big business. That there may be merit in such a position judging it by economic theory,

${ }^{18}$ U. S. v. American Linseed Oil Co., et al., supra, notes II, I4.

${ }^{10} 262$ U. S., at page 388. 
there can be no doubt whatever. But many who would sympathize with the idea still would not agree that the so-called regulatory measures be left to those who control the industry.

Mr. Justice Holmes dissented in the Hardwood Lumber case on the ground that he always understood that freedom of speech is a right guaranteed under the Constitution. The trouble with Mr. Justice Holmes' position is that he evades the whole question. He recognized no Constitutional difficulty in the Debs case in declaring that the speeches of $\mathrm{Mr}$. Debs constituted a violation of law. To test the legality of statements made or statements written are not as simple as those that he suggests in his dissenting opinion in the Hardwood Lumber case. It all goes back to the question whether the statements made are of a criminal nature. So whether Mr. Justice Stone's opinion represents the correct view, or Mr. Justice McReynolds' position represents the correct view, it is difficult to appreciate the opinion of Mr. Justice Holmes.

If the rule of stare decisis still obtains, then the business community finds itself in this position; on the authority of the Hardwood Lumber case, ${ }^{20}$ it is illegal for a combination to distribute pursuant to agreement among its members, information regarding prices and production; but on the authority of the Cement and Maple Flooring cases, it is legal to distribute such information if a fictitious cost accounting system is also used.

It should not be overlooked that the Sherman Law does not set forth the contracts and agreements which the Congress deemed were in restraint of trade. It was the intention of Congress that the statute should be interpreted in the light of English and American cases dealing with such contracts and agreements, thus making judicial legislation inevitable. ${ }^{21}$

For thirty-five years the Supreme Court has been working on a body of law with regard to this important statute and after thirty-five years' labor it is submitted that it has made no progress in its interpretation. The community is in no better position today to determine which contracts violate the Sherman Law and

${ }^{20}$ Supra, notes 14, 16.

${ }^{11}$ U. S. v. American Tobacco Co., supra, note I3. 
which do not, than it was on the second of July, I890. It is suggested that such a change of position as we find in the Maple Flooring case should make a Trial Court feel compunction in imposing jail sentences on defendants convicted of a violation of the Sherman Law. The business community might fairly have expected that the courts would define a body of law that it can follow. Few lawyers would be willing to take the position at the present time that they can foretell with any degree of certainty what agreements would be declared violative of the Sherman Law.

\section{IV}

\section{CONCLUSION}

It would, perhaps, be unwise to repeal the Sherman Law until some other method is tested. President Wilson thought that a Federal Trade Commission would bring, about the desired result. Experience, however, has demonstrated that it represents a supine body trying to work wheels that will not turn. It is hampered from without, it is hampered from within and in addition is being crushed by its own weight. Business men will not co-operate with it, because the Federal Trade Commission is without power to grant immunity against criminal prosecution. Business men scorn it because at best it can merely issue injunctive orders. The Commission itself has fettered its effectiveness by undertaking every complaint that was thrown in its path.

Caution must, therefore, be exercised before adopting the various proposed remedies contained in recent contributions to the literature on this subject. In addition, we pause to enquire, "Does the enactment of the Anti-Trust Laws reflect sincere governmental judgment that business should be regulated and monopolies and combinations destroyed"? Or is it merely a legislative enactment designed to pacify the popular clamor, "Down with the trusts"?

We question the integrity of governmental conduct which allows an expenditure of about a half-million dollars to prosecute the glass industry and at the same time enacts a Fordney Tariff to keep Belgium glass out of the home market. 
It would seem that the tariff can strike a serious blow to trust combinations. When the Tariff Commission learns from other governmental agencies that an industry is violating the trust laws, it should, whenever possible, regulate the tariff so as to bring the industry in competition with foreign markets. No weapon, it would seem, could be exerted with equal effectiveness. Yet the sinister activities of trust combinations are pursued by the Department of Justice on the one hand, and fed with the bounty of tariff protection on the other.

Besides the potential power of the tariff, what substitute can be offered for the anti-trust laws? Hesitant in assertion one must be for the reasons indicated. Ultimately, we prophesy, this method will be invoked; either the Federal Trade Commission or a new body will be established with power to regulate the large industries such as steel, coal and oil. That body will be vested with power similar to that granted to the Interstate Commerce Commission. It will regulate these industries in every sense that the Interstate Commerce Commission now regulates the railroads.

The treatment to be accorded to smaller industries which still require individual initiative and adventurous undertaking will largely depend on the sincerity of governmental action. A sincere governmental attitude will deny the protection of the tariff to any industry that has by combination agreements destroyed competitive enterprise.

New York City.

Nathan Probst, Jr. 